\title{
Post Scriptum: Hybrid Warfare and the Yugoslavian Blueprint
}

Abstract With the recent development of Russian international politics, it is of interest to revisit Yugoslavia and discuss the lessons learnt there in the light of hybrid warfare. The events in Yugoslavia in the 1990s resemble in parts to what has been described as hybrid warfare in Ukraine in 2014-2017.

Keywords Hybrid warfare $\cdot$ Russia $\cdot$ Kosovo $\cdot$ Ukraine

Hybrid warfare has as a term travelled a lot in definition. It started as a description of the Israeli debacle in Lebanon 2006, there it was seen as an empirical theorisation of Hezbollah possessing advanced weapon systems and still not being a state actor. ${ }^{1}$ From there, one can speculate what the new hybrid threats can constitute from both future inventions as nanotechnology and biohacking to contemporary cyber threats. ${ }^{2}$

\footnotetext{
${ }^{1}$ Håkan Gunneriusson (2012, p. 49). Much inspiration has been given by Frank G. Hoffman and his work on hybrid threats. Frank G. Hoffman (2009).

${ }^{2}$ Ibid. p. 63 and Håkan Gunneriusson and Rain Ottis (2013).

(C) The Author(s) 2017 
The war in Ukraine which started with the Russian annexation of Crimea can be said to take the term hybrid warfare into another direction. ${ }^{3}$

The Russian occupation and the following annexation of the Crimea peninsula were very much enabled because the large number of ethnic Russians on the peninsula. Some were for the annexation; some were bystanders and some others were against it. But they gave a minimum of legitimacy to the occupation as it could be claimed that the population wanted to secede from Ukraine and join Russia. There is a history to this and it be explained with Yugoslavia as an inspiring scenario. The term hybrid warfare was not conceptualised back then, but it may as well have been forged. There are similarities between the Crimea annexation and some of the elements in the break-up of Yugoslavia. There was an urge to create nation states to replace Yugoslavia which encompassed many different Slavic nations. This can be seen and was also seen as a state building process, more than an example of hybrid warfare. The break-up did not happen by proxy as in Crimea. The cleansing of Knin (Kninska Krajina) in Croatia, on the other hand, can be seen through the perspective of hybrid warfare even if the term still was not conceptualised, and the Serbian minority's claim for autonomy from Croatia was unsuccessful as a whole. The Serbs, who undoubtedly had lived in the region for hundreds of years, wanted to secede from the new state of Croatia, they declared themselves autonomous. The support from another new state, Serbia, can be seen as a parallel to the Russian support in Crimea and Russia's proxy involvement there. ${ }^{4}$ The difference was that Serbia lacked all resources to effectively include Knin in its war efforts-at least beyond rhetorical statements. Furthermore, there was just an ad hoc plan without further thought of support to Knin from Serbia, in effect not just a lack of capacity but a lack of planning too. The

\footnotetext{
${ }^{3}$ Sascha Bachmann and Håkan Gunneriusson (2017).

Håkan Gunneriusson and Sascha Bachmann (2015a, b). More about hybrid warfare in Håkan Gunneriusson and Sascha Bachmann (2015a, b). Håkan Gunneriusson and Sascha Bachmann (2014). Håkan Gunneriusson and Sascha Bachmann (2017). Amos C. F., and Rossow A.J. (2017).

${ }^{4}$ The lack of land connection between the splinter region and the country encouraging the break up exists in both examples. This is of course not an argument for hybrid warfare, but it can be stated just to remind that the Knin was as much of a satellite of the ethnic mother country as Crimea is.
} 
claim of independence by the local Serbs was based on the fact that the Serbs lived in Knin, there was no doctrine other than nationalistic ethos. Further, Serbia under Milošević lacked all types of symbolic capital to successfully wager such claims for their own part or for that part for Knin as a separate entity. Russia, an active supporter of Serbia then and now, stood by and could nothing do. During Yugoslavia's downfall, Russia was weak both politically and military. All Russia could do was to take notes for their new doctrine while it was a one-off operation for NATO, as with the example of Kosovo discussed below. ${ }^{5}$ Did they do that? Most certainly, if not anything else the head of Russia's General staff and the creator of its contemporary doctrine Valerij Gerasimov himself states that Yugoslavia during the 1990s was an example of NATO hybrid warfare. ${ }^{6}$

Another example of a proto-hybrid event is the administrative unit of the Republic of Srpska, which consisted of the eastern part of Bosnia. The Republic of Srpska is by no means recognised as a separate state, it is still a part of Bosnia but has little to do with the rest of the country and the issue is settled as being so for the time being. Autonomy for the area is thus not achieved, nor does Serbia formally control the territory, so this proto-hybrid warfare event was merely semi-successful. If Serbia had the political and foremost comparative military leverage, they could easily have done or yet still do a Crimean hybrid warfare operation there at any time. But being military weak and in the political process of joining the EU there is little to gain by such an approach, they did not have or currently have the capacity to act freely. We have to look elsewhere at the parting of Yugoslavia to find a more hybrid-like scenario. Something classified as a successful hybrid warfare operation can be said to have happened in the example of Kosovo. This is a good example as the process of splitting Kosovo from Serbia was very sensitive for the regime in Russia, and they took it as an unfair stripping of territory from its ally Serbia. This is not dissimilar to the Crimea situation with the USA

\footnotetext{
${ }^{5}$ The mastermind behind Russia's new doctrine is Valery Gerasimov. He presented his ideas in the following article: "The value of science in anticipation. New challenges require rethinking the forms and methods of warfare". http://www.vpknews.ru/articles/14632 [170509].

${ }^{6}$ VPK News, number 10 (674) 15th March 2017, abridged version of the report "Modern War and current national defence issues" (authors translation) for the Academy of War studies. http://www.vpk-news.ru/articles/35591 [170509].
} 
backing Ukraine and Russia separating Crimea from Ukraine. In the process of separating Kosovo, it was a stroke of symbolic violence that NATO delivered to Russia, displaying Russian weakness in the Balkans and overall. It also presented Russia with the pretext for its operation in Crimea, the sword of seceding showed to be two-edged and thus useful for Russia as well. Kosovo was staged carefully by the USA and her allies and backed both by civilian tools represented by the UN as well as the OSCE, including the military tool-NATO. Pushing for a greater self-governing of Kosovo initially, NATO presenting a peace treaty to the Serbs. However, this treaty included a paragraph that certainly would be hard for any state to accept as it included free movement and bases by a foreign military alliance (NATO) on the sovereign soil of Serbia and free movement through all of Serbia for NATO-troops. This paragraph ensured that the treaty failed and opened for military aggression. It can be argued back and forth if this paragraph really mattered, if it was raised by the Serbs or not in the negotiations. ${ }^{7}$ What is not debatable is that the paragraph was in the agreement refused by the Serbs. Refusal by the Serbs led to aggression on part of the international community with a few expectations and after a 10 -week long ordeal Serbia finally agreed to the terms of NATO. The United Nations and OSCE quickly deployed and started the building of local and central institutions for governing of a state. ${ }^{8}$ Furthermore, the legal framework was more or less completely changed in the nine years that followed until the Kosovo Albanians declared unilateral independence, backed on the way there and after by NATO as led by the USA. ${ }^{9}$ The illusio, the rules of the field of international law, was changed with Kosovo, and the change was then confirmed with Crimea when two major international actors on the field, NATO and Russia, had used this new logic of practice for international law. ${ }^{10}$ Important to note is that the actions taken to separate Kosovo from Serbia was an ad hoc solution to a problem limited in time and space. Nothing else came out of this new way to interpret international

\footnotetext{
${ }^{7}$ http://news.bbc.co.uk/2/hi/europe/682877.stm [170509].

${ }^{8}$ http://www.osce.org/ [170509].

${ }^{9}$ The change of the legal system and various institutions were facilitated by the United Nations and the OSCE through the backing by member states, as well as aid provided by the EU, USAiD and DiFiD to just name a few.

${ }^{10}$ Instead of new one can see it as a reversal of the old practice of Realpolitik.
} 
law. Russia took notes and saw a new pattern in this, a new way to act and added it to its foundation for contemporary warfare. They re-coded their understanding of warfare so that they could have their way with their neighbours like Georgia and Ukraine, primarily while still claiming deniability. One can with right argue that Russia also lacked symbolic capital in their claim to Crimea, as for Serbia in the Knin example above. But Russia could point to a host of factors in favour of Russia. Among them the claim that Crimea historically (pre-Stalin) was Russian, along with the ethnic presence of Russians there. More importantly, the ability to pursue a narrative like the one of Putin's Russia can be fruitful from their perspective. The loss of Kosovo for the Serbs can be seen as both as a material loss and a symbolic loss. Russia used the narrative from the case of Kosovo, even if not openly stating it, as a legitimating tool for the annexation of Crimea. It helped them in their effort to build the required minimum of legitimization for their annexation, at least they can hold an argument for it. Furthermore, Russia's massive military supremacy in the region talks for Russia's success as there is not really much to do in military terms about Russia's activities in Ukraine; realpolitik beats finesse in many cases, as in this example. That is the reason why the EU and NATO do not stand up for conventions against war of aggression in the case of Ukraine. The West do not have the capability to challenge Russia in the region, so it is easier to look the other way. It can be seen as a case of Reflexive control. This is an old Soviet approach called reflexive control. The psychologist Vladimir Lefebvre defines reflexive control as "a process by which one enemy transmits the reasons or bases for making decisions to another". ${ }^{11}$ The concept of reflexive control can in fact be used with bourdeiuan field theory as approach as there are similarities shown in this text. The author Timothy Thomas means that reflexive control can be used on all levels of warfare. ${ }^{12}$ One of the most complex influence operations is to influence a state's decisionmaking process. ${ }^{13}$ Russia's warfare against the West can be described as reflexive control, resulting in hybrid warfare.

\footnotetext{
${ }^{11}$ Quoted in Timothy (2004. p. 238).

17, 2004. https://www.rit.edu/ w-cmmc/literature/Thomas_2004.pdf.

${ }^{12}$ Timothy (2004. p. 239).

17, 2004. https://www.rit.edu/ w-cmmc/literature/Thomas_2004.pdf.

${ }^{13}$ Ibid, Thomas, L. Timothy.
} 
In the case with EU and NATO vs Russia today, we have a difference compared to the cold war; even if we do not believe the Russian narrative at all, we still do not challenge it fully and call Russia out for waging a war of aggression in Ukraine. Nevertheless, Russia's warfare against Western power can be described as reflexive control, resulting in hybrid warfare in the meeting with the Western powers. It all depends on who is listening, but Russia clearly sent a message to all in the region and beyond, no matter what they thought about it. The Russian doctrinal stance of hybrid warfare is now operational, and we have yet to see the end of it.

\section{REFERENCES}

Amos, C. F., \& Rossow, A. J. (2017). Making sense of Russian hybrid warfare: As of the Russo-Ukrainian war. Arlington: The Institute of Land Warfare.

Sascha Bachmann \& Håkan Gunneriusson (2014). Terrorism and cyber attacks as hybrid threats: defining a comprehensive approach for countering 21 st Century Threats to Global Peace and Security. Journal for Terrorism and Security Analysis, Syracuse University, 26-37.

Sascha Bachmann \& Håkan Gunneriusson. (2015a). New Threats to Global Peace and Society. In Scientia Militaria - South African Journal of Military Studies. 77-98.

Sascha Bachmann \& Håkan Gunneriusson. (2015b). Russia’s Hybrid Warfare in the East: Using the Information Sphere as Integral to Hybrid Warfare. In Georgetown Journal of International Affairs - International Engagement on Cyber V: Securing Critical Infrastructure. 199-211.

Gunneriusson, H. (2012). Nothing is taken seriously until it gets serious: Countering hybrid threats. Defence Against Terrorism Review, 4(1). 97-108.

Gunneriusson. H., \& Ottis, R. (2013). Cyberspace from the hybrid threat perspective. The Journal of Information Warfare, 12(3). 97-108.

Gunneriusson, H., \& Bachmann, S. (2017 upcoming). Western Denial and Russian control. How Russia's national security strategy threatens a Westernbased approach to global security, the rule of law and globalization. Polish Political Science Yearbook 2017.

Hoffman \& Frank. (2009). Hybrid warfare and challenges. Joint Forces Quarterly (52). 34-40.

Timothy, T. L. (2004). Russia's reflexive control theory and the military Journal of Slavic Military Studies, 17, 238. https://www.rit.edu/ w-cmmc/literature/Thomas_2004.pdf [170509]. 
Open Access This chapter is licensed under the terms of the Creative Commons Attribution 4.0 International License (http://creativecommons.org/licenses/ by $/ 4.0 /$ ), which permits use, sharing, adaptation, distribution and reproduction in any medium or format, as long as you give appropriate credit to the original author(s) and the source, provide a link to the Creative Commons license and indicate if changes were made.

The images or other third party material in this chapter are included in the chapter's Creative Commons license, unless indicated otherwise in a credit line to the material. If material is not included in the chapter's Creative Commons license and your intended use is not permitted by statutory regulation or exceeds the permitted use, you will need to obtain permission directly from the copyright holder.

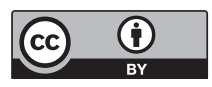

